\title{
What is museology and what should it be? A reflection on how today's museological thinking came into being
}

\author{
HANS-JAKOB ÅgotNes
}

If we go back fifty years, scholarly writing on museums, at least in Norway, normally accepted the museum institution as a fact, without asking fundamental questions about the mechanisms of the institution's knowledge production or its role in reproducing established social relations. Museum curators with education in humanistic disciplines (and I am mainly thinking of museums of cultural history here) would orient themselves towards historical subjects that were central to the content of their museum's mediation, without questioning the character of the museum institution itself. Perhaps we could say that museology is born when the scholars' perspective shifts from the subject matter of the museum to the museum itself. Museology has the museum as its object.

I don't think one could say that museology has grown into a discipline, in spite of earlier intentions inside the International Committee of Museums, and in spite of the establishment of specialized education programmes in Nordic countries. Rather, it is a perspective pursued by practitioners of different humanistic and social scientific disciplines, directed towards a common field of study. Researchers investigate this field by means of methodologies from their own fields. Historical disciplines tend to favour historical analyses, the social sciences to be more sociologically oriented. Despite this, and even if museum studies today cover a wide range of topics, they have a critical approach in common. Museologists ask fundamental questions about the existence of museums, and about the way they work - and they do so at different levels, from the practical day-to-day activity and its consequences, to the epistemological questions involved in production and mediation of messages. "The museum object" and its connection to knowledge has for example been subjected to thorough analysis, from different angles. Museums are not any more seen as neutral mediators of information. When they classify, periodize and describe, and when they select and deselect topics for mediation, they simultaneously shape our understanding of reality. This insight is a major contribution of museology: it has established a gaze from the outside on the museum institution which has made possible a theoretical understanding of museum questions that were earlier nonexistent.

What about museology's impact outside the academic sphere? The museological perspective, with its critical questioning of museum practices, has at times met a hostile attitude from museum curators. Today, museology seems (again in a Norwegian context) to be more or less universally accepted inside the museum institution as valuable and interesting - and necessary. We must consider 
the museum sector's changing role in society as a background for this shift. Museums are becoming more closely integrated in public administration, and thereby also becoming more central to cultural politics. During the last decades, the state has adopted a more and more explicit museum policy, with ambitions to influence museum practice. That critical museological perspectives have had a clear impact on the museum policy is evident in governmental political documents on museums and cultural policy. Thereby they also influence museums. In Norway at least, state authorities keep a close watch over the management of museums, controlling that they take seriously the signals to prioritize specific tasks and topics. And since the beginning of the 2000s, a state-driven consolidation of the museum sector has taken place, resulting in the merging of earlier autonomous institutions into larger units. The reorganization has probably made museum organizations more open both to stately directives and to the museological gaze. Seeing one's own organization from the outside is nearer to hand when it is in a process of reshaping.

Museological perspectives have no doubt also had an impact on opinion in the general public. Even so, conflicts may arise between museums and local communities if the museum launches controversial issues in its mediation, in keeping with a critical attitude. It is difficult to assess the effects of such conflicts; often, they seem to be about bindings between the museum and local people, i.e., cultural identity. When museums stress "difficult topics" in their mediation, one could reason that this will isolate the museum from local audiences. Another theory may be that conflicts have an overall positive effect, because they further reflection both on the subject matter (historical questions) and on the relation between the inhabitants and the museum. Here is a topic

The motivation for prioritizing "difficult questions" finds support in museological thinking on two grounds. Theoretically, investigating conflicting views is a way to reach new insights and avoid reproducing established truths. But it is also in keeping with the view that museology should influence museum practice in order to further the museums' role as institution that stimulate debates on questions of current social and political interest. For example, museological perspectives have been central in debates on museums' duty to mediate the histories of women, ethnic groups and minorities that have previously been invisible in museum exhibitions. The debates on the nationalistic character of museum messages, seen in the light of new immigration to the Nordic countries, have opened for more varied messages, at least to a certain extent. The awareness of cultural variation is probably very different today than before the 1990s.

Museological questions could also concern the more abstract relation between the museum and the public. What makes the museum attractive to visitors? For many museums, this is a vital question, since visitor numbers is important for their economic survival. For museology, it is a question of theoretical interest. The social role of the museum is connected to the meaning it has for the public, and visitors' opinion is an important indicator of the quality of museum mediation.

My wish for the future of museology is that it should be basically an empirical discipline. There are important normative tasks for the museum sector to handle, this much is true. Discrimination in a society characterized by inequalities is definitely a question that should interest museums, and the political role they play must be considered. But in 
146 my view, museological research should take as its point of departure the investigation of what museums are, how they work, and the effects they have. It should have a descriptive intention, thereby producing material for the normative decisions that museums have to take. One normative question that I find important, is how we could make the museum institution more democratic, in the sense that the knowledge it produces becomes more accessible and easier to influence for the public, without at the same time eroding the authority of the scholarly expertise. Is it possible to think that the museum and its visitors may learn from each other in a truly reciprocal way? Museological research on how the relation is in fact working would be a starting point for exploring the question.

The flourishing of scholarly museological literature during the last decades is more or less contemporaneous with the life of The Journal of Nordic Museology, both internationally and in the Nordic countries, even if there were important forerunners. The critical perspectives which have the museum institution as their object now represent the state of the art in museum studies. As more and more specialized museologists are becoming educated in coming years, we may hope for a consolidation of the field. Development of more rigorous methodologies would be a good thing, e.g. in visitor studies. But maybe we should also hope that museology will preserve its multidisciplinary character. The plurality of theories, ways of reasoning, and methodologies may prove fruitful in extending our understanding of museums in the future too.

Hans-Jacob Ågotnes, Associate Professor of Cultural Studies

Hans-Jacob.Agotnes@uib.no

Department of Archaeology, History,

Cultural Studies and Religion

University of Bergen

Postboks 7805

N-5020 Bergen, Norway 